\title{
Family business and business dynasties: A case study of Russia
}

\author{
Julia Murzina \\ Department of General and Social Psychology, \\ University of Tyumen, \\ Tyumen, Russian Federation \\ j.s.murzina@yandex.ru
}

Natália Turčeková

Slovak University of Agriculture in Nitra,

Faculty of Economics and Management,

Nitra, Slovakia

nturcek@gmail.com

\section{Elena Mensh}

Department of Foreign Languages and Intercultural Professional,

Communication,

Institute of Socio-Humanitarian Sciences,

University of Tyumen,

Tyumen, Russian Federation

menshelena@inbox.ru

\section{Joanna Nakonieczny}

Faculty of Management,

Rzeszow University of Technology,

Poland

j.nakonieczny@prz.edu.pl

Abstract. Family business and family business dynasties are notorious all around the world. The Waltons, the Fords, the Hiltons, the Bushes, the Kardashians, or the Murdochs - all of them shape up the world's globalized economy. However, in Russia business dynasties are just passing through the stage of their initial development and setting. As a result, very little empirical research has been carried out so far to determine socio-physiological traits of its incumbents. This paper describes the peculiarities of the 'founders of business dynasties' (i.e., a group of business owners who have already worked with their relatives and

\footnotetext{
Received: December, 2017 1st Revision: March, 2018 Accepted: May, 2018 
wanted to transfer their firm to the next generation) in Russian and worldwide. The paper has been built under an ex-post-facto pilot scheme. Our data collection was carried out through polling of 90 persons, all subjects being owners, proprietors, or performing the duties of the director of a business company. Our results reveal some differences between the founders of business dynasties and other three groups of business owners (called 'Singles in business', 'Dreamers', or 'The last link in business'). However, a highly significant correlation was found only in strong belief of the 'Founders of business dynasties' in usefulness of family relationships for business. This finding suggests a significant role of family relationships in business. Our results provide thus evidence on the continuing search for a secret of harmony in business-family relationships among 'the Founders of business dynasties' and its further spread within business community.

Keywords: family business, entrepreneurship, psychology, business dynasties, business succession.

JEL Classification: D10, D22, M20

\section{INTRODUCTION}

The Independent article published on March 20, 2014, announced that Bill Gates, the richest man on the planet, bequeathed almost all his money to a charitable foundation. According to his claims, his three children must earn their living themselves (The Independent, 2014). According to him, children should know the value of the money they earned. The owner of Microsoft explained that his children are free in their actions and can do whatever they want but they are not going to be showered with money that will allow them sit back and relax. His idea of depriving children of a huge inheritance was borrowed from Warren Buffett who did the same arrangement in his family.

Russian businessman Vladimir Potanin (in 2015 he became the richest businessman in Russia) decided to follow this example. He stated his readiness to transfer his fortune to charity. Potanin's children supported his idea. Such kind of owner's decision (refusal to transfer business) can completely undermine the succession of generations and the model of business dynasties itself. However, the described examples are the exceptions to general rules. In European countries, the USA and Canada, for more than 20 years already, systematic work has been carried out to study and support family businesses. The contributions of these countries to world economy and social stability are very significant.

Since 1994, recommendations are being developed to improve the business environment. Every year they are replenished and improved (Business-Dynamics research 2011). This is probably why two-thirds of British enterprises are a family business. Their contribution to the country's GDP is estimated at more than 25\% (IFB 2017), this is half of the total contribution of all SME entities in 2015 (Global Entrepreneurship Monitor, 2017).

In modern Russia, there is no specific statistics on the enterprises of family type. There are also no specialized scientific institutions engaged in the development of this type of business. According to the Global Entrepreneurship Monitor 2016/17, contribution of all small and medium-sized enterprises to Russia's GDP did not exceed 21\%. And contribution of family firms into this indicator cannot be actually measured (Figure 1). 


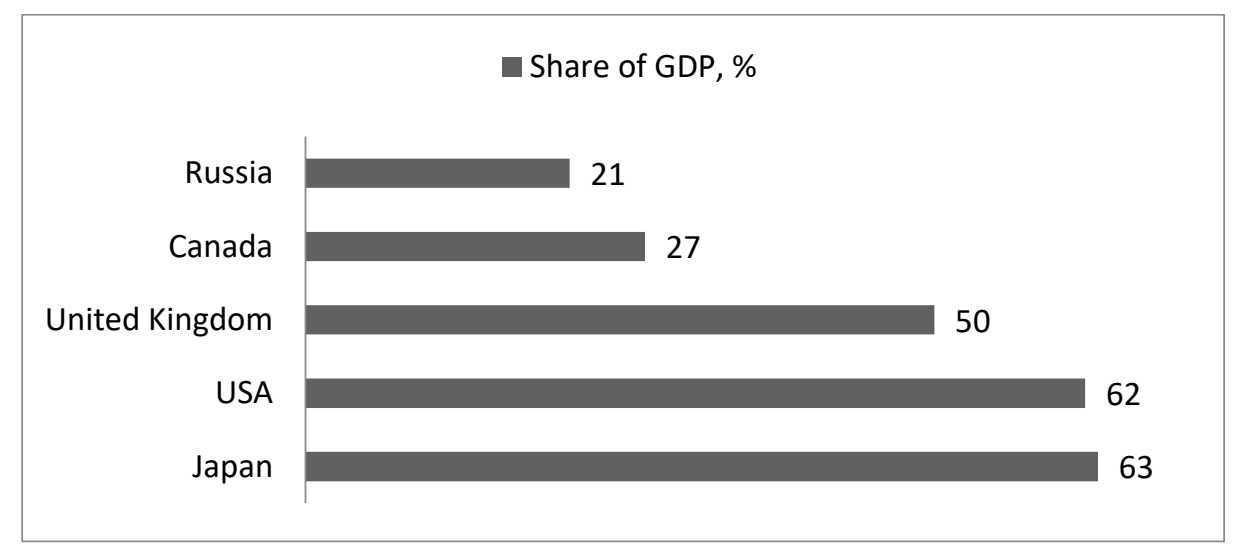

Figure 1. Contribution of small and medium business in the countries' GDP, \% Source: Global Entrepreneurship Monitor (2017)

At the same time, many European scientists provide a clear structure for the representation of SMEs in European economy (Simionescu et al., 2017). The model is characterized by the absolute dominance of family enterprises in the microbusiness sector (up to 10 people), providing employment for population, social stability and preserving the traditions (Ivanová, 2017). In explaining the absence of such work in our country, some objective and subjective reasons can be called. Among the objective reasons for this we need to mention a relatively short history of entrepreneurship in contemporary Russia and also sharp fluctuations in the growth rates of Russian economy as compared to the world ones. Let us briefly dwell on this.

Firstly, family business in Russia is just passing through the stage of its establishment after the 70-year ban on engaging in entrepreneurial activity, which was lifted only 30 years ago. That is why the first businessmen of the 1990s are now entering the age when it is necessary to think and plan the transfer of affairs to the new generation. Therefore, there is no practice of studying and supporting family business: family companies develop independently and spontaneously, experiencing a number of typical difficulties.

Secondly, the growth rate of Russian economy in comparison with the world one shows the large amplitude of fluctuations (IMEMO, 2016). Unpredictability of these fluctuations increases the fear of entrepreneurs concerning the instability of the future.

Probably, the consequences of the described above factors form the subjective reasons for low development of SMEs in Russia. For example, low level of entrepreneurial intentions among the Russians. According to the Global Entrepreneurship Monitoring (GEM) data as of 2017, only 2.1\% of the Russians, who are not entrepreneurs, are ready to start their own business, while the indicator 'Fear of failure' demonstrates a very high result - $44.8 \%$. The indicator of 'Entrepreneurial intentions' is one of the lowest for the entire sample of 64 participating countries (GEM, 2017).

In the context of the current situation, there are initiatives of the Government of the Russian Federation, as a result of which positive changes in the business environment are realized. So, in October 2016 the World Bank has issued an updated rating of 'Doing Business 2017'. Rating traditionally includes 190 countries and assesses the convenience and ease of doing business (Becerra-Alonso et al., 2016). The assessment takes into account many factors, such as the speed of registration of enterprises, access to electricity, the level of tax burden, etc. By 2017, Russia, according to the World Bank Group, has come in a better shape. This is evidenced by a higher $(+13)$ position in 2016: 40th place against 54th in 2015. The rating compilers note that it is much easier for Russia to register and conduct business. 


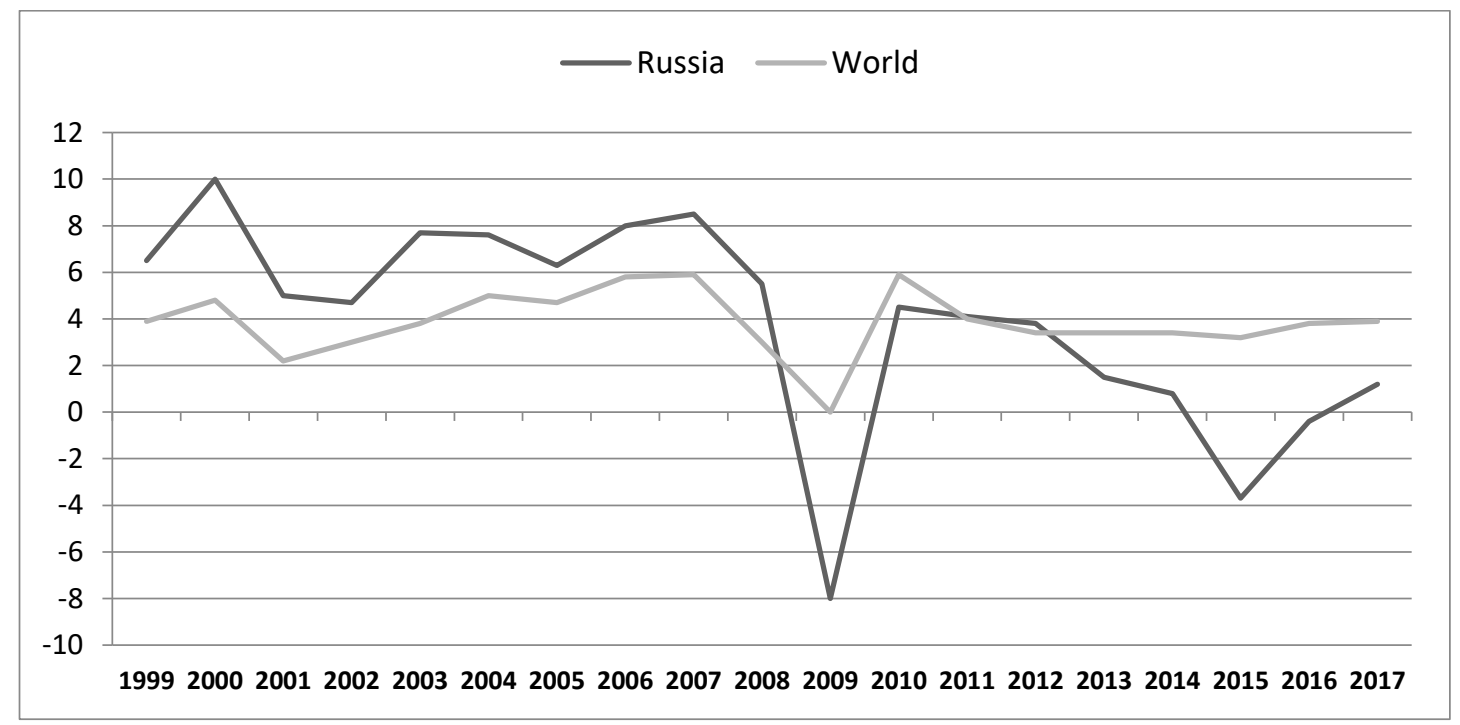

Figure 2. Growth rates of Russian and world economy, in \%

Source: GEM (2017)

Finally, regionalization will be the future significant socio-economic trend for Russia and the world. Foundation for Advanced Studies and Initiatives 'Russia and the World - 2017' (IMEMO, 2016) suggests that world globalization is in doubt. This point of view is based on the accelerated development of the processes of regionalization: the Brexit, the victory of Donald Trump in elections, the strengthening of the positions of anti-globalists in European countries. Similar moods related to the orientation towards the domestic product, a conscious rejection of foreign goods, support of the domestic producer should be expected in Russia.

Therefore, the theme of the socio-psychological study of the revival of family business in our country today acquires particular urgency. It contributes to the strengthening and development of SMEs and the creation of a new social class of entrepreneurs, doing socially responsible business and valuing the family name and reputation of their business. Our research is intended to remove uncertainty concerning characteristics of the new arising social striations in the society 'Founders of Business Dynasties'. It will help to reveal an internal resource of development of medium and small business subjects, to estimate expediency of measures for support of this type of business and to give an impetus for their substantial filling.

\section{LITERATURE REVIEW}

Le Breton-Miller et al. (2004) made an analysis of scientific journals of the late $20^{\text {th }}$ century in the context of studying the family business. The view from the Incumbent was prioritized. In this regard, such aspects as Motivation, Willingness, Quality of incumbent-successor relationships (respect, understanding, trust, cooperation, personality, needs). The Incumbent must face normal fears such as losing control, power, and even part of his or her identity and stature in the community (Potts et al., 2001). There is too much need to make emotionally wrenching choices from among one's children, siblings, and collaborators (Malone, 1989). Although these are psychologically draining issues, Sharma et al. (2001) conclude that the predecessor's inability 'to let the business off' is the single most cited obstacle to effective succession.

In the second place in the popularity of the study was the Successor. In this direction, the following questions are touched upon: quality incumbent-successor relationships (respect, understanding, trust, cooperation and closeness), motivation (interest, commitment to family owned business perpetuation as a 
family value, freedom or an option not to join family business), competence, talent, experience, credibility and legitimacy.

Modern researchers view the problem of modern business or family business from the different angle using system-based approach (e.g. Armas-Cruz, 2017; Janda et al., 2013; Ehrenberger et al., 2013; Koudelková \& Svobodová, 2014; Kalyugina et al., 2015; Ključnikov et al., 2016, Andreeva et al., 2016; Jankelová et al., 2017; Ślusarczyk \& Baryń, 2018; Vovk, \& Vovk, 2017; Žižka et al., 2018; Ussahawanitchakit, 2017). Furthermore, Tagiuri and Davis (1996) suggested ways how to identify a main specificity and to analyse the source of conflicts and priorities in family enterprises. Their model illustrates the family business system composed of three independent subsystems: business, ownership, and family. Family firms are specific because a specific set of stakeholders/shareholders is involved: the members of a family (a three circle-model).

On the basis of this model, Bergamaschi and Randerson (2016) composed typology of the corporate social responsibility and family business in different four configurations (Instrumental, Pragmatic, Utopist, Engaged). We suggest viewing these very subsystems of family business as key ones for searching of significant characteristics of CEO.

The general contour of researches on family business can be outlined by the concept three 'A'. As pointed out by Nordqvist and Melinin (2010), family business is framed within three themes: actor, activity and attitude. Taking it into account they make the point that any research in some specific area within these three themes can greatly contribute to theoretical and empirical understanding of entrepreneurship and family business. Our research belongs to the first component ('Actor'): we study founders of business dynasties - the businessmen wishing to continue the business in the succeeding generations (Ślusarczyk \& Baryń, 2018). Lumpkin, Brigham, and Moss (2010) proposed that long-term orientation of family business can be positively associated with innovativeness, proactiveness, and autonomy but negatively associated with risk taking and competitive aggressiveness. Our research offers an approach from the position of interrelation study of the owner's characteristics and business with long-term orientation.

As many researches show, the gender of the entrepreneur is an important key point. We should pay our attention to this feature in the empirical part of the work (Krejčí et al., 2015). According to Mathews and Moser (1995), males are more interested in owning their own small business than females. Following Mathews and Moser (1995), who believe that family background, sex and work experience are significant signs of interests in small firm ownership and employment, we point out such variables in studying small firm ownership as sex, experience of business activity and working sphere of the company. In a similar vein, Rodríguez-Ariza et al. (2017), having analysed 550 international firms and comparing the role of female directors in family and non-family firms, found out that in family firms corporate social responsibility commitment does not depend significantly on the gender of a director.

Interconnection of a family, relations and business is another important part of the theoretical researches within our work. De Beer et al. (2015) discuss the importance of journalists for business (De Beer et al., 2015), while Koudelková et al. (2015) analyse the role of corruption in SMEs. Some aspects of human resource management are viewed by Elicegui-Reyes (2016). They point out that the links between family and their emotional ties are an important part of human resource management. They study theoretically how emotional capital can be a key factor both for attracting and retaining talent and for ensuring competitiveness in economic, social and environmental aspects. Holt and Popp (2013) argue that business history and social science studies of family firms pay insufficient attention to the emotional elements of a family. Whereas, they greatly affect family firms, distinguishing them from each other as distinctive variables, and treating them from a rationalising perspective. In studying family businesses, the significant attention is paid to researching emotions in business. Kellermanns et al. (2014) carry out the systematic research of emotions in business families: generalise existed approaches, propose modern 
tendencies, and suggest the perspective for future researches. Memili et al. (2015) study the peculiarities of role conflict in families. They propose that role conflict in family firms reduces the family firm performance. Positive interconnection of family and business is studied by Craig et al. (2014). They reveal that family positively influences family culture. Consequently, family culture upgrades strategic flexibility and this flexibility positively improves firm innovativeness, benefitting firm performance.

Graham and Seaman (2016) develop a metaphoric analogy - 'the DNA of the family business'. It allows consider the complexity of family business relationships and also their capacity for change. The ability of DNA to mutate gives an opportunity for development and change within family business. Transfer of DNA of family business is realised not biologically and happens in the course of training of the next generation of successors. Our reasoning leads to the fact that the information transferred to successors in family business is a code basis - DNA 'molecule'. It is noted by Indarti and Kusuma (2016) that mainly predecessors transfer tacit knowledge to their successors and this knowledge includes knowledge of the product and company management, technical and philosophical knowledge. Knowledge sharing in family business is also under consideration of Cunningham et al. (2016). They investigate the nature of knowledge sharing in small family firms and explore the role of the influence of family in knowledge resource development. In that context we can address the research done by Stanley et al. (2017) which shows latent profile analysis's superior ability to capture complex patterns of important family firm characteristics. They demonstrate how profiles can be linked to differences in dependent variables, providing family firm scholars with a tool to assess heterogeneity and its consequences among family firms.

The question about expediency of family business transfer to the heirs and its success is raised in the work of Mehrotra et al. (2013). The group of researchers come to the conclusion that in Japan inherited family firms are important and generally perform well. They prove that non-consanguineous heir-run firms exceed blood heirs' firms. At the same time, blood heirs defeat professional managers at running family firms. From the point of view of Bennedsen et al. (2015), families can manage their firms better because they are able to make contributions that non-family managers cannot provide, though there are problems from within the family and outside, which challenge family ownership. The authors propose a family business map, describing evolution of ownership and control of results.

As features of historical and political development of Russia cause our research we will stop on consideration of the modern researches in family business having a national context. The question about the origin of continuity in family business and the beginning of business dynasties is urgent for the Russian reality. As our region is geographically closer to Asian community, we observe some researches based on national characteristics of family business in this area. As for China, the relevance is connected with the subject of one-child policy. As stated by Cao et al. (2015) due to the one-child policy family firms experience lack of human capital in family succession. Zheng (2012) is interested in the influence of public listing on the transformation of family business and the growth of economies in three main China locations: Shanghai, Taiwan and Hong Kong.

Gender aspect in family business succession is studied by Mathew (2016). It is a well-known fact that most of the countries in Asia are prejudice to male supremacy in family. It is concluded that women could be successful successors of family business. Frank and Landström (2016) described core characteristics of family business research, which make it attractive. According to them an interesting research should be subjective, novel, relevant, evoking emotional responses.

Our research implies using of our own typology of CEOs therefore we present other's approaches to empirical typology of business owners. Complying the following typology of family firms can be done using the following parameters: company goals, cultural characteristics of the organization and owner management style. The above typologies give an opportunity to 'see' a typical portrait of the owner - the founder of business dynasties in those countries where entrepreneurship was able to develop freely for many 
centuries. However, in their basis, the typologies presented have external and economic grounds for isolation. Our research suggests the inclusion of gender and social characteristics of the business owner.

The study of the effectiveness of family firms led to the understanding of interweaving of emotional and functional dimensions in business (Mitchell et al., 2003). It is generally accepted that effective family firms tend to achieve a combination of financial and non-financial goals (Davis \& Taguiri, 1989; Olson et al., 2003; Stafford et al., 1999). Sharma (2004) proposes to distinguish family firms in assessing the development of family and business relationships. The presented typology of relations in business families has become very popular abroad due to its simplicity and good practical application. Therefore, it created a precedent for continuing scientific research in this direction.

Let us describe the family business researches in Russia during last years. According to Price Waterhouse Coopers (PwC) (2016) which annually monitors private family business in Russia and 50 countries, issues of continuity and conflicts between family members caused the least concern among $2 \%$ of family members. The greatest problem of business, as leaders believe, is the instability of the general economic situation in the country (69\%), although in 2015 67\% of private companies showed growth.

As noted in the $\mathrm{PwC}$ report, $57 \%$ of entrepreneurs have prescribed procedures and mechanisms for resolving family conflicts ( $+12 \%$ by 2014 ), which is well below the global average of $82 \%$. However, the revealed positive trend demonstrates that the culture and management system in Russian family enterprises is being improved, creating a basis for stable development in the future (PWC, 2016).

The importance of formalizing procedures is noted by most owners who have already transferred the role of management to the members of new generation of the family. Formal management mechanisms are important for ensuring healthy family relationships and continuity between generations.

The Research Centre of Welfare and Philanthropy SKOLKOVO implemented a project to study private capital and family business. The respondents were owners of capital from 30 million US dollars in the amount of 32 people. The relevance of the study seems to us indisputable, because the resolution of the issue of continuity in large companies directly affects the economic stability of the country.

According to the results of the survey, it turned out that owners of large capital in more than $60 \%$ do not involve family members in business. At the same time, businessmen are ready to bequeath their welfare to children and family members (50\%). By 2016, the succession plan has been developed only for a few owners $(18 \%)$, and as a succession mechanism (to reduce the importance): wills, trust, insurance, private family fund. This leads us to the idea that the owners of large capital in Russia do not plan the distant future of their business, perceiving it as an opportunity to provide 'here-and-now,' rather than a means to perpetuate their family name, continue the family business and philanthropy. Pre-revolutionary traditions (before 1917) of the family business of such dynasties as the Morozovs, the Demidovs, the Ryabushinskys, etc., unfortunately, are not an example to follow.

From our point of view, without the response of the owners of large-scale capital, the initiative of SKOLOKOVO on the creation of 'Family Offices' in Russia will remain. According to the research results, large family business companies expressed their unwillingness to structure their fortunes through trusts and family funds $(73 \%)$, but prefer to invest as assets, buying shares in other companies (82\%). Based on the results of the studies of the Centre for Welfare Management and Philanthropy, a social stake of the owner of large capital was drawn up. He looks like this: a man of 41-50 years old, married once, having many children, having a diploma in special education in business and management, started his business in the 1990s. The creation of such a social and psychological portrait is the goal of our research on the founders of family dynasties in Russia at the level of small business. As our previous studies show, unlike the owners of large capital in Moscow, small businesses (in the regions) are thinking of including children in their own business and extending their business in the next generation of the family. 
Turning to socio-psychological research in the field of family business and entrepreneurship, we note the 'starting point' by Schumpeter. He developed an 'innovative theory of entrepreneurship', in which special attention was paid to entrepreneurs-innovators, who profit from the introduction of innovations. Since the work of Schumpeter, in the economic literature attempts are made to define the entrepreneur not only as a subject of economic activity, but as a person of a special psychological type.

Zhuravlev and Poznyakov (2012) was at the very beginning of the emergence of entrepreneurship as a social group in Russia (1993-1994). The auther described the socio-psychological typology of subjects of economic activity. The empirical data obtained by the author on samples from different social groups made it possible to single out the following socio-psychological types of subjects of economic activity: 'Traditional', 'Forced Business Activity,' 'Passively Adjustable,' 'Conditionally Active,' 'Actively Realizing '. Suggested types are characterized by a different combination of psychological relationships and real behavior. They differ in the degree of coherence of psychological relations as elements of economic consciousness and business activity. The subjective psychological criterion of the mismatch of psychological relations and real behavior is the general satisfaction of the subject with the activity performed.

This study is of interest due to the comparability of the conditions of the conduct: based on the established ideas about the change of generations in 25 years:

- mid-1990s - the emergence of entrepreneurship in Russia;

- 2007-2010 - a change of generations and the birth of the first line of dynasties in business.

The issue of the importance of the family in business was indirectly examined in the study of value orientations of entrepreneurs using the adapted version of Rokich's method (Zhuravlev \& Poznyakov, 2012). As a result, the following structure of the most preferred terminal values of entrepreneurs was found (in descending order): health, family, material security, self-confidence, work, freedom, friends, love. Within this structure, reliable differences in the values of 'material security' and 'health' were found. Orientation to these values among entrepreneurs from the cities of Central Russia is expressed stronger. Moscow businessmen have higher 'family' and 'love' values, but the differences between estimates are not significant.

The obtained data on a sample of entrepreneurs by Zhuravlev and Poznyakov (2012) coincide with the results of studies conducted by other authors on a similar program both for entrepreneurs and representatives of other segments of the population of Russia. On the basis of these studies, it can be concluded that there are no fundamental differences in the structure of meaningful life values among entrepreneurs from other segments of the population. Values such as health, family, material security, freedom, work, friends and love are among the ten most important practically at all levels of the Russian population. At the same time, in the hierarchy of terminal values of entrepreneurs, a comparatively more important place is occupied by such values as material security, self-confidence, freedom and active life. Among the instrumental values, entrepreneurs appreciate independence, efficiency in business and entrepreneurship.

However, the Russian scientists, being in some isolation from world tendencies due to internal political features of our country for many years denying a private property and business, just now bring to notice studying of family business and its owners. In previous studies, we showed that, despite such difficult economic conditions, the family business is attractive to its owners. Most of the owners of small and medium-sized businesses are motivated to transfer cases to the next generation, members of their families (more than 64\%). We also revealed the interest of entrepreneurs themselves in building business dynasties.

With regard to the above, the questions how family business in Russia develops and how possible founders of business dynasties in our country look like become paramount. The aim of this investigation is to describe the main characteristics of the 'Founders of business dynasties.' The existence of significant 
priorities in the system of values in the entrepreneurial environment gives us the opportunity to put forward the first hypothesis: 'Founders of business dynasties' are characterized by a greater orientation (statistically significant) in family relations, planning their business for several years ahead, adhering to the growth strategy.

The second hypothesis of our work will be the assumption that the selected types of entrepreneurs with respect to the transfer of firms by inheritance will differ significantly. All this will help to identify the internal resource development of SMEs, assess the feasibility of measures to support this type of business and give impetus to their content.

\section{RESEARCH TOOLS AND METHODS}

In the previous research (Murzina 2015, 2016), we suggested to divide into types the owners of business according their attitude to descending the firm. 'Desire of respondents to transfer the business to children' (existence / absence) was the first criterion in this classification. The second criterion - 'Form of busines'(family / non-family business).

In accordance with two designated criteria we distributed respondents in the matrix in four quadrants. We designated their representation through percentage distribution in the selection (Figure 6). The names to four types of businessmen were chosen conditionally: we tried to capture metaphorically the main essence of each form of the attitude.

\begin{tabular}{|c|c|c|}
\hline $\begin{array}{r}\text { I would like to } \\
\text { transfer business to } \\
\text { children }\end{array}$ & $\begin{array}{c}\text { 'Dreamers' (3) } \\
31 \%\end{array}$ & $\begin{array}{c}\text { 'Founders of dynasties' (4) } \\
33 \%\end{array}$ \\
\hline $\begin{array}{r}\text { I would not like to } \\
\text { transfer business to } \\
\text { children }\end{array}$ & $\begin{array}{c}\text { 'Singles in business' (1) } \\
19 \%\end{array}$ & $\begin{array}{l}\text { 'The last link' (2) } \\
17 \%\end{array}$ \\
\hline
\end{tabular}

Figure 3. The typology of the owners of business according to their attitude to descending the firm Source: Own results

To test the suggested hypothesis the following parameters of comparison were selected on the basis of the theoretical views of Tagiuri and Davis (1996):

(1) subjective estimation of an economic condition of business and business planning,

(2) social and demographic characteristics of the owner and inclusion of his/her family in business,

(3) social and psychological assessment of the importance of a family in business.

The object of study is the entrepreneurs of micro, small and medium business. The subject of research is social and psychological characteristics of the owners of business belonging to the conditional social type 'Founders of dynasties'. There are three experimental variables:

(1) A dependent variable - characteristics of owners of business.

(2) An independent variable - the businessman's type according to the selected typology 'Founders of dynasties', 'Dreamers', 'The last link', 'Singles in business'. 
(3) Controlled variables - gender, age, number of people in the company (including cases if relatives work), the period of the company's existence.

Thus, the study was built under an ex-post-facto pilot scheme. Data collection took place by method of an interview (telephone survey) and questioning. Telephone survey took no more than 10 minutes. Questioning took place in the form of personal filling of questionnaires after which completeness of data was surely estimated. 90 people -45 representatives of family and 45 of nonfamily business took part in the inquiry. All respondents are owners acting as directors. The companies - the enterprises (Self-employed Persons and Limited Liability Partnerships) working in the following directions of business: public catering, services sector, trade, production of food, industrial production, training and trainings, rural economy, information technologies, services of maintenance of cars, cargo transportation, hotel service, tourism, construction.

Table 1

Characteristic of selection

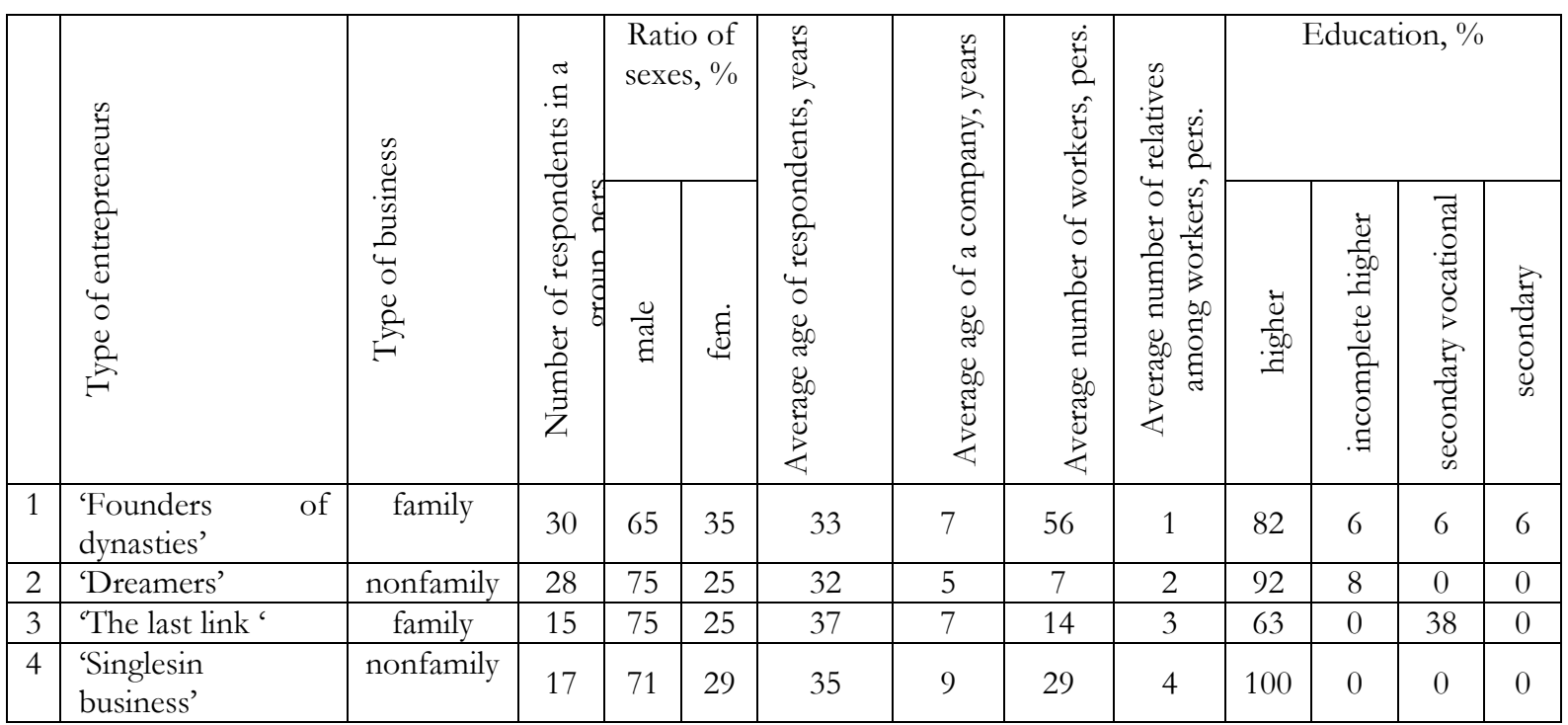

The selection strategy of respondents from population is randomization, which is a procedure of casual distribution of respondents for groups (family and nonfamily business).

\section{EMPIRICAL MODEL: RESULTS AND OUTCOMES}

The obtained data were transferred by the method of poll of 90 respondents to the Microsoft Excel program. Further, all examinees were carried to one of four theoretically allocated types. Reference to this or that type was coded through a dichotomizing scale (0-1).

To check the first hypothesis of existence of statistically significant characteristics of 'Founders of dynasties' we used a method of the correlation analysis, a way of account 1-Pearson. For interpretation of indicators of the correlation analysis we used a settled system of an assessment of the importance of connection:

$0-0,3$ - correlation connection is very weak;

$0,3-0,5$ - weak;

$0,5-0,7$ - average; 
0,7-0,9 - high;

0,9-1 - very high degree of correlation.

The truncated correlation connections are presented in Table 2 .

Table 2

Empirical results - table of correlations

\begin{tabular}{|c|c|c|c|}
\hline Type of entrepreneur & 1. Owner & 2. Business & 3. Family \\
\hline 'Founders of dynasties' & $\begin{array}{c}\text { Arts education }(-0,3) \\
\text { Relatives work in business } \\
(0,7)\end{array}$ & Transport companies $(0,4)$ & $\begin{array}{c}\text { Family relations belp in } \\
\text { business }(0,6)\end{array}$ \\
\hline 'Dreamers' & $\begin{array}{c}\text { Relatives work in business (- } \\
0,6)\end{array}$ & $\begin{array}{l}\text { Business strategy: } \\
\text { stagnation (without } \\
\text { changes) }(-0,3)\end{array}$ & $\begin{array}{c}\text { Family relations prevent } \\
\text { business }(0,6)\end{array}$ \\
\hline 'The last link' & $\begin{array}{c}\text { Business planning: the } \\
\text { next several months }(0,4) \\
\text { Education: secondary } \\
\text { vocational }(0,3)\end{array}$ & $\begin{array}{c}\text { Business strategy: } \\
\text { stagnation (without } \\
\text { changes) }(0,3) \\
\text { Business problem: lack of } \\
\text { own business education } \\
(0,3)\end{array}$ & - \\
\hline 'Singles in business ' & $\begin{array}{l}\text { Children don't help in } \\
\text { business }(0,3) \\
\text { Arts education }(0,3) \\
\text { Relatives work }(-0,4)\end{array}$ & $\begin{array}{c}\text { Business strategy: } \\
\text { merger/absorption }(0,4) \\
\text { Problems in business: } \\
\text { complexity / inaccessibility } \\
\text { of programs of state } \\
\text { support }(-0,3) ; \\
\text { imperfection of crediting } \\
\text { system (high interests) } \\
(-0,3) \\
\text { Education: Arts }(0,3) \\
\text { Field of activity: public } \\
\text { catering }(0,4)\end{array}$ & $\begin{array}{c}\text { Family relations belp in } \\
\text { business }(-0,3)\end{array}$ \\
\hline
\end{tabular}

To check the second hypothesis of the importance of distinctions between types of businessmen we carried out the statistical analysis of data with use of Student' T-test. The results are presented in Table .

Table 3

Meanings of Student' t-test foruntied selections

\begin{tabular}{|c|c|c|c|}
\hline & Type 'Dreamers' & Type 'The last link ' & Type 'Singles in business ' \\
\hline $\begin{array}{c}\text { Type 'Founders of } \\
\text { dynasties' }\end{array}$ & 0,2 & 0,5 & 0,3 \\
\hline
\end{tabular}

Critical values

\begin{tabular}{|c|c|}
\hline \multicolumn{2}{|c|}{ T-test } \\
\hline $\mathrm{p} \leq 0.05$ & $\mathrm{p} \leq 0.01$ \\
\hline 1.99 & 2.64 \\
\hline
\end{tabular}




\section{DISCUSSION OF RESULTS}

As it can be seen from Table 3, the most significant correlation links have been found in the type 'Founders of dynasties' with the criterion 'Family relations help business' (0,6). It means that in creation of family dynasties, neither characteristics of the owner (gender, age, education, etc.) nor a way of doing business (business strategy, prospect of planning, etc.) have paramount value. The qualitative characteristics of the existing relations in the family play an important role.

It leads us to a thought that manifestation of 'weakness' of the family relations can be traced through conscious refusal from creation of business dynasties on Bill Gates, Warren Buffett or Vladimir Potanin's examples and through revealed tendencies of modern Russian 'capitalists' not to involve families in business. In a solid and close-knit family where one of the members is doing business, the issue of business transfer will probably be resolved unambiguously and positively.

Other links found in the correlation analysis (Table 3) have the weak importance and can be discussed at the hypothetical level. So, arts education won't be characteristic of the type 'Founders of dynasties'. It is most likely that humanitarians won't create business with participation of relatives and transfer it to the descendants. This idea can be proved by positive correlation link at level 0,3 of the type 'Singles in business' and arts education. Possibly, it is that type of business which deals with personal peculiarities of its founder and impossibility 'to broadcast' the created business.

High correlation link with the characteristic 'Relatives work in business' $(0,7)$ is an artefact and serves only as confirmation that 'Founders of dynasties' are family firms. However, lack of significant correlation with the characteristic 'Children help in business' demonstrates that small family business includes not only direct relatives (father - son), but also minor ones (brothers, sisters, nephews, etc.). The weak correlation at level 0,4 between the type 'Founders of dynasties' and the characteristic 'Business sphere': transport companies' also deserves our attention. At the level of the assumption this correlation gives us an opportunity to consider the sphere of transport services as the territory of origin of future family dynasties.

It is not our task to consider in detail other three types of businessmen as we have concentrated our attention on 'Founders of dynasties'. Besides, the correlation links revealed in them are weak. An exception is the interrelation established for the type of businessmen 'Dreamers'. According to our logic of the typology creation, 'Dreamers' are a type of businessmen who have no relatives in business today, but would like to descend it to children. At the same time, the correlation analysis shows significant interrelation with negative 'Influence of the family relations on business'. Businessmen of this type consider that family relations spoil business. Therefore, their plans about creation of business dynasties will remain, most likely, declarative.

Summing up testing of the first hypothesis, we can state its partial confirmation: 'Founders of business dynasties' are characterized by bigger orientation to the family relations. No peculiarities in long-term planning of business and the choice of business strategies were revealed.

For testing of the second hypothesis we have compared the allocated types of businessmen on the importance of distinctions Student' T-test (Table 4 and Figure 8). The percentage expression in all studied parameters (Owner - Business - Family) was used in comparison of four types. The received coefficients demonstrated insignificant distinctions between 'Founders of dynasties' and other types of businessmen ('Dreamers', 'The last link', 'Singles in business'). On the one hand, it can mean that the parameters for an assessment 'Owner - Business - Family' have no sufficient distinctive force. On the other hand, the reason can lie in types of businessmen - they are similar in an economic assessment of business, social and demographic characteristics of owners and the relation to a family. The second hypothesis hasn't received the confirmation. 


\section{CONCLUSION AND POLICY IMPLICATIONS}

At the present stage of economic development, family business endures a stage of the first transition to the new generation of successors. However, the studying of family business in Russia is not so popular, despite experience of foreign countries where institutes, private and state funds for studying and development of family business work. Therefore, the contribution of the family enterprises to GDP of EU countries remains so significant. In this respect, the aim of our research was the revealing of significant characteristics of the type' Founders of dynasties' in Russian small and medium business.

Our empirical results demonstrate that in creation of family dynasties qualitative characteristics of the developed relations in the family are of significant importance. Taking as a basis the model of Tagiuri and Davis (1996), we came to the conclusion that namely the first subsystem 'Family' is the key one in forming family dynasties. Neither characteristics of the owner (gender, age, education, etc.) nor the way of doing business (business strategy, the prospect of planning, etc.) have paramount value. The help in increasing the number of small and medium enterprises through development of the state family policy and institution of the family can become practical use of the received results.

In addition, we can also elaborate on possible restrictions of the research. Firstly, the empirical base has a small distortion - numerically, unequal groups of businessmen are used for comparison. Secondly, businessmen at the age of 33-35 participated in our research. It would be efficient to involve in a further research the businessmen at the age of 50 and above.

Nevertheless, our results about the importance of the family relations in formation of business dynasties allows us to draw the following conclusion: it is necessary to form in public consciousness such a social norm as briefing children on family values, traditions and family business. Thereby, the unity of a family by means of collaboration and efforts on ensuring financial wellbeing can be formed. The municipal Centres of business development together with the Family Centres could organize work on creation of the information occasions and actions, which draw attention to the importance of such briefing.

Our results can find their practical use in implementation of the prioritized national Russian Federation project 'Small business and support of an individual enterprise initiative' and in increasing the number of small and medium enterprises. Such help can be realized through development of institution of the family. Strengthening in families of businessmen traditional values, formation of the common family interests and traditions, increase in unity, decrease in proneness to conflict through formalization of procedures of continuity and formal mechanisms of management, creation of the plan of continuity - all these can create a social and economic tendency to formation of business dynasties. Taking into account the world tendency to regionalization, improvement of business conditions and the planned gain of economy, it is possible to present the creation of business dynasties as a new social and economic 'trend'. Such work will serve to continuation of the best traditions of pre-revolutionary business dynasties in Russia.

\section{REFERENCES}

Andreeva, E. L, Simon, H., Karkh, D.A., \& Glukhikh, P.L. (2016). Innovative entrepreneurship: a source of economic growth in the region. Economy of Region, 12(3), 899-910. https://doi.org/10.17059/2016-3-24

Armas-Cruz, Y., Gil-Soto, E., \& Oreja-Rodríguez, J. R. (2017). Environmental management in SMEs: organizational and sectoral determinants in the context of an Outermost European Region. Journal of Business Economics and Management, 18(5), 935-953. doi: https://doi.org/10.3846/16111699.2017.1373375

Becerra-Alonso, D., Androniceanu, A., \& Georgescu, I., (2016). Sensitivity and vulnerability of European countries in time of crisis based on a new approach to data clustering and curvilinear analysis. Administratie si Management Public, (27), 46-61. 
Bennedsen, M., Fan, J. P. H., Jian, M., \& Yeh, Y. H. (2015). The family business map: Framework, selective survey, and evidence from Chinese family firm succession. Journal of Corporate Finance, 33, 212-226. https://doi.org/10.1016/i.jcorpfin.2015.01.008

Bergamaschi, M., \& Randerson, K. (2016). The futures of family businesses and the development of corporate social responsibility. Futures, 75, 54-65. https://doi.org/10.1016/j.futures.2015.10.006

Business Dynamics: Start-ups, Business Transfers and Bankruptcy. The economic impact of legal and administrative procedures for licensing, business transfers and bankruptcy on entrepreneurship in Europe. 2011. http://www.cbs.dk/files/cbs.dk/business_dynamics_1.pdf

Cao, J., Cumming, D., \& Wang, X. M. (2015). One-child policy and family firms in China. Journal of Corporate Finance, 33, 317-329. https://doi.org/10.1016/j.jcorpfin.2015.01.005

Craig, J. B., Dibrell, C., \& Garrett. R. (2014). Examining relationships among family influence, family culture, flexible planning systems, innovativeness and firm performance. Journal of Family Business Strategy, 5 (3), 229-238. https://doi.org/10.1016/i.jfbs.2013.09.002

Cunningham, J., Seaman, C., \& McGuire, D. (2016). Knowledge sharing in small family firms: A leadership perspective. Journal of Family Business Strategy, 7(1), 34-46. https://doi.org/10.1016/i.jfbs.2015.10.002

Davis, J. A., \& Tagiuri, R. (1989). The Influence of Life Stage on Father-Son Work Relationships in Family Companies. Family Business Review, 2(1), 47-74. https://doi.org/10.1111/j.1741-6248.1989.00047.x

De Beer, A. S., Láb, F., Strielkowski, W., \& Tejkalová, A. (2015). Business influence on media news processing: a comparison of journalists' perceptions in the Czech Republic and South Africa. Economics and Sociology, 8(1), 222-233. http://dx.doi.org/10.14254/2071- 789X.2015/8-1/17

Doing Business (2017). Rating Doing business. Accessed 20 February 2017 . Available at: http://www.doingbusiness.org/ /media/WBG/DoingBusiness/Documents/AnnualReports/English/DB17-Report.pdf

Ehrenberger, M., Koudelkova, P., \& Strielkowski, W. (2015). Factors influencing innovation in small and medium enterprises in the Czech Republic. Periodica Polytechnica: Social and Management Sciences, 23(2): 73-83. http://dx.doi.org/10.3311/PPso.7737

Elicegui-Reyes, J. I., J. Barrena-Martínez, \& Romero-Fernández, P. M. (2016). Emotional capital and sustainability in family businesses: Human resource management perspective and sustainability. In: CSR 2.0 and the new era of corporate citizenship, edited by M. A. Camilleri, 231-250. Malta: IGI Global. https://doi.org/10.4018/978-1-52251842-6.ch012

Frank, H., \& Landstrom, H. (2016). What makes entrepreneurship research interesting? Reflections on strategies to overcome the rigour-relevance gap. Entrepreneurship and Regional Development, 28(1-2), 51-75. https://doi.org/10.1080/08985626.2015.1100687

Global Entrepreneurship Monitor (2017). Global Report 'Global Entrepreneurship Monitor - 2016/17. Available at: http://www.gemconsortium.org, Accessed 15 February 2017

Graham, S., and Seaman, C. (2016). Harmonizing the family business: Deconstructing the DNA of the family business. In The modernfamily business: Relationships, succession and transition, edited by L. Collins, 210-226. UK: Palgrave Macmillan. https://doi.org/10.1057/9781137001337 7

Holt, R., \& Popp, A. (2013). Emotion, succession, and the family firm: Josiah Wedgwood and Sons. Business History, 55 (6), 892-909. https://doi.org/10.1080/00076791.2012.744588

IMEMO. (2016). Ezhegodnyj prognoz IMEHMO RAN 'Rossiya i mir 2017: ehkonomika i vneshnyaya politika'. 2016. [Annual forecast of the IMEMO RAS 'Russia and the World 2017: Economics and Foreign Policy']. 2016. Accessed on: February 15th 2017 . Available at: http://www.imemo.ru/index.php?page id=645andid=3490

Indarti, N., \& Kusuma, G. H. (2016). Types of Knowledge Transferred in Family Business Succession. 2016 IEEE International Conference on Industrial Engineering and Engineering Management (IEEM):646-650.

Institute for Family Business. (2017). UK Family Business. Accessed March $15 \quad 2017$. http://www.ifb.org.uk/voice/uk-family-business/

Issledovanie vladel'cev kapitalov Rossii. (2015). [Investigation of Russian capital owners]. Accessed on: February $10^{\text {th }}$ 2017. http://wtc.skolkovo.ru/ru/wtc-home/research/vladeltsy-kapitalov-rossii 
Ivanová, E. (2017). Barriers to the development of SMEs in the Slovak Republic. Oeconomia Copernicana, 8(2), $255-272$. doi: https://doi.org/10.24136/oc.v8i2.16.

Janda, K., Rausser, G., \& Strielkowski, W. (2013). Determinants of Profitability of Polish Rural Micro-Enterprises at the Time of EU Accession. Eastern European Countryside, 19, 177-217. https://doi.org/10.2478/eec-2013-0009

Jankelová, N., Jankurová, A., \& Masár, D. (2017). Effective management and self-government: current trends. C飞ech Journal of Social Sciences, Business and Economics, 6(2), 21-31. http://doi.org/10.24984/cjssbe.2017.6.2.3

Kalyugina, S., Strielkowski, W., Ushvitsky, L., \& Astachova, E. (2015). Sustainable and secure development: facet of personal financial issues, Journal of Security \& Sustainability Issues, 5(2), 297-304. http://doi.org/10.9770/jssi.2015.5.2(14)

Kellermanns, F. W., Dibrell, C., \& Cruz, C. (2014). The role and impact of emotions in family business strategy: New approaches and paradigms. Journal of Family Business Strategy, 5(3), 277-279. https://doi.org/10.1016/j.jfbs.2014.08.002

Ključnikov, A., Belás, J., Kozubíková, L., \& Paseková, P. (2016). The Entrepreneurial Perception of SME Business Environment Quality in the Czech Republic. Journal of Competitiveness, 8(1), 66-78. doi:10.7441/joc.2016.01.05.

Koudelková, P., \& Svobodová, P. (2014). Knowledge creation \& sharing as essential determinants of SMEs innovation. International Economics Letters, 3(1), 12-20. http://dx.doi.org/10.24984/iel.2014.3.1.3

Koudelková, P., Strielkowski, W., \& Hejlová, D. (2015). Corruption and system change in the Czech Republic: Firmlevel evidence, DANUBE: Law and Economics Review, 6(1), 25-46. https://doi.org/10.1515/danb-2015-0002

Krejčí, M., Strielkowski, W., \& Čabelková, I. (2015). Factors that influence the success of small and medium enterprises in ICT: a case study from the Czech Republic. Business: Theory and Practice, 16(3), 304-315. https://doi.org/10.3846/btp.2015.521

Le Breton-Miller, I., Miller, D., \& Steier, L.P. (2004). Toward an integrative model of effective FOB succession. Entrepreneurship-Theory and Practice, 28(4), 305-328.

Liu, Y. S., Chen, Y. J., \& Wang, L. C. (2017). 'Family business, innovation and organizational slack in Taiwan.' Asia Pacific Journal of Management 34 (1):193-213. https://doi.org/10.1007/s10490-016-9496-6

Lumpkin, G. T., Brigham, K. H., \& Moss, T. W. (2010). Long-term orientation: Implications for the entrepreneurial orientation and performance of family businesses. Entrepreneurship and Regional Development, 22(3-4), 241-264. https://doi.org/10.1080/08985621003726218

Malone, S.C. (1989). Selected correlates of business continuity planning in the family business. Family Business Review, 2(4), 341-353.

Mathew, V. (2016). Women and family business succession in Asia - characteristics, challenges and chauvinism. International Journal of Entrepreneurship and Small Business, 27, (2-3):410-424. https://doi.org/10.1504/IJESB.2016.073972

Mehrotra, V., Morck, R., \& Shim, J. Wiwattanakantang, Y. (2013). Adoptive expectations: Rising sons in Japanese family firms. Journal of Financial Economics, 108(3), 840-854. https://doi.org/10.1016/j.jfineco.2013.01.011

Memili, E., E. P. C. Chang, F. W. Kellermanns, \& D. H. B. Welsh. 2015. 'Role conflicts of family members in family firms. European Journal of Work and Organizational Psychology, 24(1), 143-151. https://doi.org/10.1080/1359432x.2013.839549

Murzina, J.S., \& Tonysheva, L. L. (2015). The revival of the family business in Russia: why the process is failing during the economic crisis?' The 5th International conference on Eurasian scientific development. East West Association for Advanced Studies and Higher Education Gmbh, 180-182.

Murzina, J.S., \& Tonysheva, L.L. (2016). Succession of Business in Russia: Motives for Owner's Business Transfer under the Conditions of Economic Instability. Indian Journal of Science and Technology, 9(27), 1-16. https://doi.org/10.17485/ijst/2016/v9i27/97700

Nordqvist, M., \& Melin, L. (2010). Entrepreneurial families and family firms. Entrepreneurship and Regional Development, 22(3-4), 211-239. https://doi.org/10.1080/08985621003726119

Potts, T. L., Schoen, J. E., Engel Loeb, M., \& Hulme, F. S. (2001). Effective retirement for family business ownermanagers: Perspectives of financial planners, Part II, Journal of Financial Planning, 14(7), 86-96. 
Rodrigues-Ariza, L., Cuadrado-Ballesteros, B., Martinez-Ferrero, J., \& Garcia-Sanchez, I.-M. (2017). The role of female directors in promoting CSR practices: An international comparison between family and non-family businesses. Business Ethics, 26(2), 162-174. https://doi.org/10.1111/beer.12140

Seaman, C., R. Welsh, \& R. Bent. 2013. 'Succession planning in minority ethnic family enterprises. International Journal of Entrepreneurship and Small Business, 20 (4), 402-419. https://doi.org/10.1504/IJESB.2013.057199

Sharma, P., \& Irving, P. G. (2005). Four bases of family business successor commitment: Antecedents and consequences. Entrepreneurship Theory and Practice, 29(1), 13-33. https://doi.org/10.1111/j.15406520.2005.00067.x

Sharma, P., Chrisman, J. J., Pablo, A. L., \& Chua, J.H. (2001). Determinants of initial satisfaction with the succession process in family firms: A conceptual model. Entrepreneurship Theory and Practice, 25(3),17-35. https://doi.org/10.1177/104225870102500302

Simionescu, M., Lazányi, K., Sopková, G., Dobeš, K., \& Balcerzak, A.P. (2017). Determinants of Economic Growth in V4 Countries and Romania. Journal of Competitiveness, 9(1), 103-116. https://doi.org/10.7441/joc.2017.01.07

Ślusarczyk, B., \& Baryń, M. (2018). Generation Matters? The Approach of the Family Business Representatives of Different Generations to Selected Aspects of Their Functioning [in:] Innovation Management and Education Excellence Through Vision 2020 (ed.) Soliman K. S., 31st International Business Information Management Association Conference (31st IBIMA), Milan, Italy, 25-26 April 2018, 1073-108.

Ślusarczyk, B., \& Baryń, M. (2018). Terms of the Development of Family Businesses in Selected Countries in Europe [in:] Proceedings of the 2nd International Conference Contemporary Issues in Theory and Practice of Management (ed.) Okręglicka M., Korombel A., Lemańska-Majdzik A., 2nd International Conference Contemporary Issues in Theory and Practice of Management (CITPM 2018), Częstochowa, Poland, 19-20 April 2018, 629-636.

Stanley, L., F. W. Kellermanns, \& T. M. Zellweger (2017). Latent Profile Analysis: Understanding Family Firm Profiles. Family Business Review, 30(1), 84-102. https://doi.org/10.1177/0894486516677426

Tagiuri, R., \& Davis, J. (1996). Bivalent Attributes of the Family Firm. Family Business Review, 9(2), $199-208$. https://doi.org/10.1111/j.1741-6248.1996.00199.x

The Independent (2016). Bill Gates: 'Our children won't be left billion-dollar trust funds'. https://www.independent.co.uk/news/people/bill-gates-our-children-wont-be-left-billion-dollar-trust-funds9204317.html

Ussahawanitchakit, P. (2017). Activity-based costing of canned and processed foods businesses in Thailand: effects on organizational development, business competitiveness and corporate success. Business: Theory and Practice, 18, 215-225. doi: https://doi.org/10.3846/btp.2017.023

Vovk, I., \& Vovk, Y. (2017). Development of family leisure activities in the hotel and restaurant businesses: Psychological and pedagogical aspects of animation activity. Economics, Management and Sustainability, 2(1), 67-75. doi:10.14254/jems.2017.2-1.6

Zheng, V. (2012). Chinese family business, stock market and the Haiwankong financial network. Journal of Asian Public Policy, 5(3), 277-294. https://doi.org/10.1080/17516234.2012.731179

Zhuravlev, A. L., \& Poznyakov, V. P. (2012). Social'naya psibologiya rossijskih pred-prinimatelej: Koncepciya psihologicheskih otnoshenij [Social Psychology of Russian Entrepreneurs: The Concept of Psychological Relations]. Moscow: Publishing house 'Institute of Psychology RAS'.

Zhuravleva, N.A. (2006). Dinamika cennostnyh orientacij lichnosti v rossijskom obshchestve. [Dynamics of value orientations of the individual in Russian society] Moscow: Publishing house 'Institute of Psychology RAS'.

Žižka, M., Hovorková Valentová, V., Pelloneová, N., \& Štichhauerová, E. (2018). The Effect of Clusters on the Innovation Performance of Enterprises: Traditional vs New Industries. Entrepreneurship and Sustainability Issues, (4), 780-794. http://doi.org/10.9770/jesi.2018.5.4(6) 